\title{
Žaliosios trąšos ir mineralinių trąšų efektyvumo palyginimas žieminių rugių ir miežių derliui priesmèlio dirvožemyje
}

Liudmila Tripolskaja ${ }^{1}$,

Danuta Romanovskaja ${ }^{1}$,

Alvyra Šlepetiené ${ }^{2}$

Ingrida Verbyliené ${ }^{1}$

${ }^{1}$ Lietuvos agrarinių ir mišku mokslu centro Vokes filialas,

Žalioji al. 2,

LT-02232 Traku Voke, Vilnius

El.paštas: liudmila.tripolskaja@voke.lzi.lt

${ }^{2}$ Lietuvos agrarinių ir mišku mokslu centro Žemdirbystès institutas, Instituto al. 1,

LT-58344 Akademija, Kèdainiu r.

El.paštas: alvyra@lzi.lt
Atliktų 1997-2005 m. LAMMC Vokès filiale stacionarinių eksperimentų duomenimis, ivvertinta galimybè tausojamoje žemdirbysteje naudoti sumažintą pramoninių mineraliniu azoto trą̌̌̌ kieki, javų agrocenozèje naudojant sukaupiamą žaliosios trąšos augalų biologinị azotą. Tyrimai atlikti mažo rūgštumo, vidutinio fosforingumo, didelio kalingumo priesmèlio paprastajame išplautžemyje (Haplic Luvisols) javų (miežiai, miežiai, žieminiai rugiai, avižos) agrocenozèje. Nustatyta, kad priesmèlio dirvožemyje gausesnę biomasę žaliajai trąšai suformavo pagrindiniai sèjomainos augalai (I n. m. dobilų atolas, geltonieji lubinai, nedirbamo pūdymo augalija) - vidutiniškai 3,10-3,74 t ha ${ }^{-1}$ sausųjų medžiagų, su kuriomis ị dirvožemị itterpta 50,0-83,6 $\mathrm{kg} \mathrm{ha}^{-1}$ azoto. Tarpinių pasèliu žaliajai trąšai (dobilų įsèlio, aliejinių ridikų) produktyvumas buvo mažesnis ir pasižymëjo didesne variacija nei pagrindinių sèjomainos augalų. Rudens laikotarpiu jie užaugino vidutiniškai $1,29-2,14 \mathrm{t} \mathrm{ha}^{-1}$ sausujjų medžiagų biomasę, su kuria įterpta $43,3-48,4 \mathrm{~kg} \mathrm{ha}^{-1} \mathrm{~N}$. Priesmèlio dirvožemyje žieminių rugių ir miežių tręšimas tik žaliąja trąša nepasiteisino - javų grūdų derlius, palyginti su tręšimu mineralinėmis azoto trąšomis $\mathrm{N}_{80}$, sumažèjo iš esmès: žieminių rugių - 15,6-27,6 \%, miežių - 62,2\%. Efektyvus buvo nedirbamo pūdymo augalijos žaliajai trąšai ir $25 \%$ sumažintų mineralinių azoto trą̧̌ų $\left(\mathrm{N}_{60}\right)$ derinimas. Taip trę̌iiant gautas didžiausias žieminių rugiụ grūdų derlius $\left(3,30 \mathrm{tha}^{-1}\right)$, grūdai buvo iš esmès stambesni $(+0,7 \mathrm{~g})$.

Raktažodžiai: žalioji trąša, javai, derlius, azotas

\section{IVADAS}

Lengvos granuliometrinès sudèties dirvožemiuose kartu su mineralinemis trąšomis būtina naudoti organines, kurios padeda palaikyti stabilų humuso kiekį ir pagerinti kitas dirvožemio savybes (Orlov ir kt., 1996; Krištaponytė ir kt., 2006; Maikštènienè ir kt., 2008). Pastaruoju dešimtmečiu Lietuvoje ūkininkai vis plačiau tręšimui naudoja augalinès kilmès organines trąšas, nes dèl ịvairių ekonominių priežasčių smarkiai sumažèjo gyvulių skaičius bei jų tankis atskirose vietovèse, vadinasi, sukaupiama ir mažiau měšlo. Nuolat brangstančios mineralinès trąšos skatina ieškoti alternatyvių šaltinių, tinkančių tręšti žemès ūkio augalus. Tam tikslui dažnai auginami ịvairūs pasèliai žaliajai trąšai, užariama augalų šalutinè produkcija (šiaudai, lapai), kurie padeda papildyti judriųjų augalų maisto medžiagu atsargas dirvožemyje ir palaikyti stabilų humuso balansą.

Žaliajai trąšai augalai gali būti auginami visą vegetacijos periodą arba nuemus pagrindinių sèjomainos augalų derlių. Pirmieji pasèliai auginami žieminių javų tręšimui, posèliniai augalai - kitų metų vasarojų tręšimui. Nuo žaliosios trą̧̌os paskirties ir parinktų augalų rūšies priklauso biomasės kiekis, cheminių elementų sukaupimas joje, destrukcijos procesai dirvožemyje. Visi paminèti veiksniai daro įtaką tręšiamų žaliąja trąša javų derliui ir produkcijos kokybei. Nustatyta, kad Lietuvos klimato sąlygomis didesnis žaliosios masès derlius gaunamas auginant augalus žaliajai trąšai visą 
vegetacijos periodą (Nedzinskas, Nedzinskienè, 1999; Rudokas, 2003). A. Nedzinsko ir T. Nedzinskienès (1999) duomenimis, priesmèlio dirvožemyje geriausiai dera siauralapiai ir geltonieji lubinai, o jų žaliosios masès derlius vidutiniškai siekia 27,5-28,9 $\mathrm{t} \mathrm{ha}^{-1}$ esant palankioms hidroterminèms sąlygoms - iki 32,5 t ha ${ }^{-1}$. Bastutinių šeimos augalų (aliejinių ridikų, vasarinių rapsų, baltųjų garstyčių) produktyvumas priesmèlio dirvožemyje yra menkesnis ir jie užaugina vidutiniškai 16,7-25,5 t ha ${ }^{-1}$ žaliosios masès. Sunkios granuliometrinès sudèties dirvožemiuose, kurie pasižymi didesniu natūraliu derlingumu (palyginti su priesmèliais), posèliniai aliejiniai ridikai žaliajai trąšai rudens laikotarpiu užaugina $1,30 \mathrm{t} \mathrm{ha}^{-1} \mathrm{SM}$ (Stancevičius, Trečiokas, 1996). Po posèlinių aliejinių ridikų žaliajai trąšai vasarinių kviečių derlius padidejo 24,6\% (Stancevičius ir kt., 1996). Ypač tinka žaliajai trąšai issèliniai daugiamečiai augalai su gausia šaknų sistema. A. Stancevičiaus ir kt. (1996) duomenimis, aparus gausiažiedes svidres, kviečių derlius padidèjo $16,2 \%$.

Šio darbo tikslas - ìvertinti galimybę tausojamoje žemdirbysteje sumažinti pramoninių mineralinių azoto trąšuc panaudojimą, javų agrocenozejje naudojant sukaupiamą žaliosios trąšos augalų biologinị azotą.

\section{TYRIMŲ SĄLYGOS IR METODAI}

Tyrimai atlikti LAMMC Vokès filale 1997$2005 \mathrm{~m}$. priesmèlio paprastajame išplautžemyje (pagal FAO UNESCO klasifikaciją - Haplic Luvisols). Prieš įrengiant bandymą, dirvožemis buvo silpnai rūgštus $\left(\mathrm{pH}_{\mathrm{KCl}} 5,5\right)$, vidutinio fosforingumo (124,7 $\mathrm{mg} \mathrm{kg}^{-1} \mathrm{P}_{2} \mathrm{O}_{5}$ ), didelio kalingumo (220,0 mg kg-1 $\mathrm{K}_{2} \mathrm{O}$ ), humusingas (2,34\%). Javų sèjomainoje (miežiai, miežiai, žieminiai rugiai, avižos) buvo tirtas ịvairių agrotechninių priemonių (sèjomainos struktūros, mèšlo, šiaudų, žaliosios trąšos) poveikis augalų derliui ir dirvožemio derlingumui. Šiame straipsnyje pateikti tyrimų rezultatai, kaip žaliosios trąšos veikia žieminių rugių ir miežių derlių.

Žalioji trąša buvo auginama taip: vasariniams javams - nuèmus pirmojo sèjomainos nario (miežių) derlių, kaip posèliniai tarpiniai pasèliai (dobilų ịsèlis, aliejiniai ridikai), o žiemkenčiams - antraisiais tyrimų metais, kaip pagrindiniai augalai (I n. m. dobilų atolas, geltonieji lubinai, nedirbamo pūdymo augalija). Iš visų skirtų žaliajai trąšai augalų rūšių tik aliejinai ridikai buvo tręšti mineralinèmis trąšomis $30 \mathrm{~kg} \mathrm{ha}^{-1} \mathrm{~N}$, kad galètų suformuoti didesnę biomasę. Pupinių šeimos augalai (dobilai, lubinai) turèjo pasinaudoti dirvožemyje esančiomis maisto medžiagomis, iš gumbelinių bakterijų geba fiksuoti atmosferos azotą. Žaliosios trąšos augalai, skirti žieminių rugių tręšimui, buvo aparti liepos pirmąji dešimtadienị (lubinai, nedirbamo pūdymo augalija) arba rugpjūčio pradžioje (I n. m. dobilų atolas). Posèliniai augalai žaliajai trąšai (dobilų îsèlis, aliejiniai ridikai) aparti spalio antrajj dešimtadienị.

Žieminiams rugiams ir miežiams mineralinių trąšų normos parinktos atsižvelgus $\mathfrak{i}$ augaluose sukauptas maisto medžiagas. Mineralinių trąšų normos turejjo kompensuoti maisto medžiagu kiekí, paimamą iš dirvožemio su pagrindine ir šalutine produkcija. Kontrolinị variantą sudarè (be organinių trąšų) $80 \mathrm{~kg} \mathrm{ha}^{-1} \mathrm{~N}, 60 \mathrm{~kg} \mathrm{ha}^{-1}$ $\mathrm{P}_{2} \mathrm{O}_{5}$ ir $60 \mathrm{~kg} \mathrm{ha}^{-1} \mathrm{~K}_{2} \mathrm{O}$. Kituose variantuose, kur buvo auginti augalai žaliajai trąšai, azoto trąšu norma buvo mažinama, atsižvelgus i pasirinktų augalų skirtingą potencinę gebą užauginti biomasę ir kaupti biologini azotą. Miežiai, auginti be organinių trąšų, buvo tręšti $\mathrm{N}_{80}$, auginti po dobilų isélio $-\mathrm{N}_{0}$, auginti po aliejinių ridiku $-\mathrm{N}_{30}$. Žieminiai rugiai, auginti be organinių trąšų, taip pat buvo tręšti $\mathrm{N}_{80}$, auginti po I n. m. dobilų atolo ir lubinų $-\mathrm{N}_{0}$, auginti po nedirbamo pūdymo $-\mathrm{N}_{60}$.

Augalų antžeminès dalies žaliosios masès derlius nustatytas iš $0,25 \mathrm{~m}^{2}$ ploto. Augalų šaknų mase nustatyta iškasant $0,5 \mathrm{~m} \times 0,5 \mathrm{~m} \times 0,25 \mathrm{~m}$ tūrio dirvožemio èminį. Šaknys buvo atskirtos nuo dirvožemio ir nuplautos. Sausųjų medžiagų kiekiui nustatyti augalų antžeminès dalies žalioji masẻ ir šaknys išdžiovintos $+105{ }^{\circ} \mathrm{C}$ temperatūroje iki pastovaus svorio. Visas augalo biomasès kiekis apskaičiuotas susumavus antžeminès dalies ir šaknų sausųjų medžiagų kiekį.

Mineralinio azoto migracijos dinamikai ištirti dirvožemio èminiai (įterpus žaliają trąšą) buvo paimti 1997-1998, 1998-1999, 1999-2000, 20032004 ir 2004-2005 metais rudens-žiemos-pavasario laikotarpiu kas 4-6 savaites (jeigu dirvožemis buvo nę̨šalęs). Ėminiai imti 0-25, 25-40, 40-60, 60-100 cm sluoksniais iš kiekvieno laukelio. Mineralinio azoto (nitratinio ir amoniakinio suma) atsargos buvo apskaičiuotos $0-100 \mathrm{~cm}$ sluoksnyje. Kiekviename sluoksnyje, ištyrus mineralinio azoto kiekį, buvo galima nustatyti jo išplovimo dinamiką 
(po žaliosios trąšos įterpimo) ir, remiantis pasiūlyta Granstedt (1995) formule: $\mathrm{N}$ išplovimo nuostoliai $=\mathrm{N}_{\text {min atsargos 0-100 cm }}$ rudeni $-\mathrm{N}_{\text {min atsargos } 0-100 \mathrm{~cm}}$ pavasarí, apskaičiuoti azoto išplovimo nuostolius (nuo rudens iki pavasario).

Augaluose buvo nustatytas suminis azotas Kjeldalio metodu (ISO 11261:19995), dirvožemyje - mineralinio azoto kiekis $\left(\mathrm{N}-\mathrm{NO}_{3}\right.$ ir $\mathrm{N}-$ $\mathrm{NH}_{4}$ - spektrofotometriniu metodu). Simbiotinio azoto kiekis apskaičiuotas pagal augalų faktinị derlingumą naudojant Hopkinso-Piterso koeficientą (Hamdy, 1982). Tyrimų rezultatai ịvertinti dispersinès ir koreliacijos regresijos analizès metodais kompiuterine programa ANOVA (Tarakanovas, Raudonius, 2003).

Pagal meteorologines sąlygas vegetacijos periodai tyrimu metais buvo: pakankamai drégni arba per daug drègni 1997, 1998, 2000, 2001, 2003, 2004 ir 2005 m. (HTK 1,71; 1,90; 2,00; 1,47; 1,59; 1,76; 2,26) ir nepakankamai drègni 1999, $2002 \mathrm{~m}$. (abiejų vegetacijos periodų HTK 0,90). Po žaliosios trąšos itterpimo (1997-1998, 1998-1999, 1999-2000, 2003-2004 ir 2004-2005 m.) žiemos laikotarpiai buvo su dažnais atodrèkiais ir šiltesni nei būdinga, išskyrus 1998-1999 m. žiemos laikotarpi, kurio metu atšilimų nebuvo.

\section{TYRIMŲ REZULTATAI IR JŲ APTARIMAS}

\section{Žaliosios trąšos biomasės derlius ir azoto sukau-}

pimas. Žaliosios trąšos poveikis po jų auginamų augalų derliui priklauso nuo keleto svarbiausių veiksnių: užaugintos biomasès ir sukaupto joje maistingujjų elementų kiekio, itterptos biomasès irimo dinamikos. Dažnai siekiama užauginti kuo daugiau biomasès, kuri galètų padidinti organinès medžiagos bei judriųju azoto, fosforo ir kalio junginių kieki dirvožemyje. Atlikus šiuos tyrimus buvo nustatyta, kad priesmèlio dirvožemyje nuo pavasario auginant pasèlius žaliajai trąšai, daugiau biomasès suformavo I n. m. raudonujų dobilų atolas $\left(2,69-4,29 \mathrm{t} \mathrm{ha}^{-1} \mathrm{SM}\right)$ ir geltonieji lubinai (2,98-4,49 t ha-1 SM) (1 pav.).

Ypač didelę ịtaką augalų biomasès derliui turèjo hidroterminès sąlygos. Pavyzdžiui, antrojoje rotacijoje dèl vasaros pradžioje nepakankamo kritulių kiekio I n. m. dobilų atolo, lubinų ir nedirbamo pūdymo augalijos žaliosios masès derlius, palyginti su pirmąja rotacija, sumažèjo atitinkamai 37,3 , 33,6 ir $42,2 \%$.

Posėlinių tarpinių pasèlių derliaus pokyčiai buvo dar akivaizdesni - dobilų issèlio biomasès derlius sumažèjo daugiau kaip 3 kartus, aliejinių

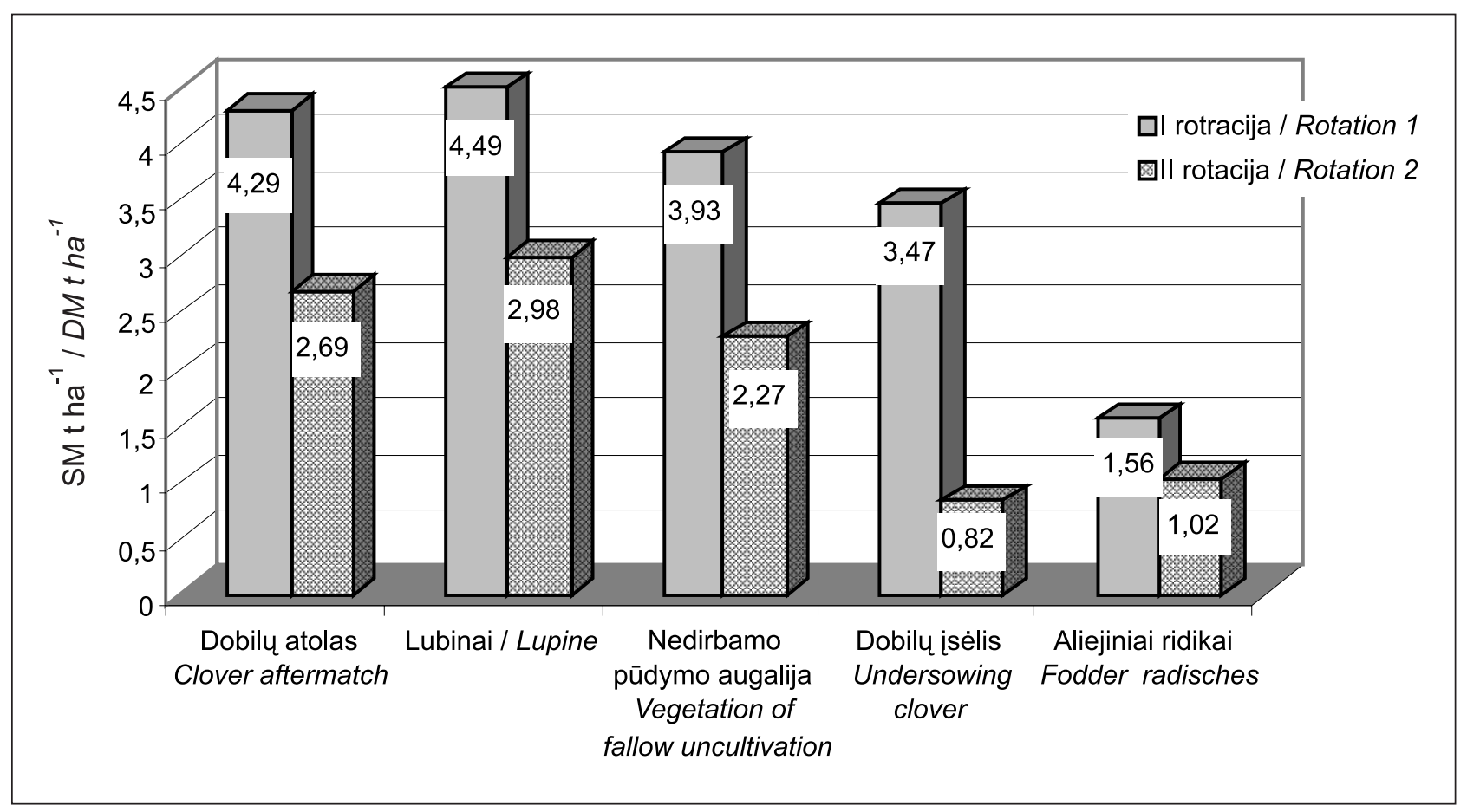

1 pav. Žaliosios trąšos augalų biomasès derlius

Fig. 1. Biomass yield of green manure plants 
ridikų - $34 \%$. Dviejų rotacijų duomenimis, I n. m. raudonujų dobilų atolo ir lubinų biomasès derlius buvo gana panašus - 3,49-3,74 $\mathrm{t} \mathrm{ha}^{-1} \mathrm{SM}$, nedirbamo pūdymo augalijos $0,39-0,64 \mathrm{t} \mathrm{ha}^{-1}$ mažesnis. Iš esmès skyrèsi biomasèje sukaupto azoto kiekis. Pupinių šeimos augalai (dobilai, lubinai) sukaupe biomaseje vidutiniškai $82,2-83,6 \mathrm{~kg} \mathrm{ha}^{-1} \mathrm{~N}$, o nedirbamo pūdymo lauko segetalinè augalija - tik $50,0 \mathrm{~kg} \mathrm{ha}^{-1}$ (1 lentelè).

Sukaupto azoto kiekiui taip pat turejjo įtakos vegetacijos periodo hidroterminès sąlygos, nuo kurių priklausè biomasès derlius. Palyginti su pirmąją, antrojoje rotacijoje dèl mažesnio biomasès derliaus azoto buvo sukaupta 22,3-56,2\% mažiau. Posèlinių augalų (dobilų ịsèlio, aliejinių ridikų) biomasès derlius buvo skirtingas - dobilai vidutiniškai užaugino 2,14 $\mathrm{t} \mathrm{ha}^{-1} \mathrm{SM}$, aliejiniai ridikai beveik dvigubai mažiau - 1,29 $\mathrm{t} \mathrm{ha}^{-1} \mathrm{SM}$. Tačiau azoto akumuliacija biomasëje buvo panaši - 48,4 ir 43,3 kg ha ${ }^{-1} \mathrm{~N}$. Tyrimų metais šių augalų derlius buvo labai skirtingas ir ypač priklausė nuo kritulių kiekio jų vegetacijos laikotarpiu. Antrojoje rotacijoje dèl drègmès trūkumo vasaros pradžioje dobilu ịsèlis blogai sudygo ir, nuėmus miežius, jau nesugebejo suformuoti pakankamo biomasès kiekio. Palyginti su pirmaja rotacija, sausųjų medžiagų derlius sumažèjo 2,8 kartus, o azoto sukaupta 3 kartus mažiau.
Žaliosios trąšos irimas ir mineralinio azoto susidarymas dirvožemyje. Aparus žaliąsias trąšas, biomasès skaidymosi greiti veikia hidroterminès sąlygos (dirvožemio drègmè, temperatūra), itterptų augalų cheminè sudètis (azoto ir anglies santykis, lignino kiekis) ir kiti veiksniai (Arlaukskienè, Maikštienienè, 2005; Brye et al., 2001; Vinther et al., 2006). Atlikus mineralinio azoto dinamikos dirvožemyje tyrimus nustatyta, kad didžiausios mineralinio azoto atsargos $0-100 \mathrm{~cm}$ sluoksnyje, žieminiams rugiams ịterpus žaliąją trąšą po pagrindinių sėjomainos augalų, susidaro rudens laikotarpiu. Nuo liepos iki lapkričio mèn. mineralinio azoto atsargos padidejo vidutiniškai $35-57 \%$. Priklausomai nuo žiemos sezono hidroterminių sąlygų, lemiančių mineralinio azoto migraciją $\mathfrak{i}$ gilesnius sluoksnius, iki pavasario mineralinio azoto atsargos vidutiniškai sumažèja 18-40\% (Romanovskaja, 2001; Трипольская, Романовская, 2006). Atlikus koreliacinę regresinę analizę tarp mineralinio azoto atsargų, susidariusių aparus žaliąsias trąšas iki žieminių rugių vegetacijos atsinaujinimo pavasarị ir ịterptos biomasés kiekio, nustatyta, kad kuo daugiau itterpiama žaliosios masès, tuo daugiau mineralinio azoto randama dirvožemyje pavasari (2 pav.). Priklausomumas tarp šių veiksnių buvo $\mathrm{R}^{2}=0,48$ (koreliacinio santykio tikimybès lygis

1 lentelè. Azoto kiekis, panaudotas žieminių rugių ir miežių tręšimui $\left(\mathrm{kg} \mathrm{ha}^{-1} \mathrm{~N}\right)$

Table 1. The nitrogen content used for winter rye and barley fertilization $\left(\mathrm{kg} \mathrm{ha}^{-1} \mathrm{~N}\right)$

\begin{tabular}{|c|c|c|c|c|c|c|c|c|c|}
\hline \multirow{3}{*}{$\begin{array}{l}\text { Organinès medžiagos } \\
\text { šaltinis } \\
\text { Sources of organic } \\
\text { matter }\end{array}$} & \multicolumn{9}{|c|}{ Iterpta azoto $\mathrm{kg} \mathrm{ha}^{-1} /$ Incorporated nitrogen, $\mathrm{kg} \mathrm{ha}^{-1}$} \\
\hline & \multicolumn{3}{|c|}{$\begin{array}{c}\text { Su mineralinèmis } \\
\text { trąšomis } \\
\text { With mineral fertilizers }\end{array}$} & \multicolumn{3}{|c|}{$\begin{array}{c}\text { Su žaliosios trąšos biomase } \\
\text { With biomass of green } \\
\text { manure }\end{array}$} & \multicolumn{3}{|c|}{ Iš viso / Total } \\
\hline & $\mathbf{I}^{*}$ & II & $\begin{array}{l}\text { Vidurkis } \\
\text { Average }\end{array}$ & I & II & $\begin{array}{l}\text { Vidurkis } \\
\text { Average }\end{array}$ & I & II & $\begin{array}{c}\text { Vidurkis } \\
\text { Average }\end{array}$ \\
\hline $\begin{array}{l}\text { Be organinių trą̧šu } \\
\text { Without organic } \\
\text { fertilizers }\end{array}$ & 80 & 80 & 80 & 0 & 0 & 0 & 80 & 80 & 80 \\
\hline $\begin{array}{l}\text { I n. m. dobiluc atolas } \\
\text { I yr. clover aftermath }\end{array}$ & 0 & 0 & 0 & 95,0 & 72,3 & 83,6 & 95 & 72,3 & 83,6 \\
\hline Lubinai / Lupine & 0 & 0 & 0 & 90,5 & 74,0 & 82,2 & 90,5 & 74,0 & 82,2 \\
\hline $\begin{array}{l}\text { Nedirbamo pūdymo } \\
\text { augalija / Vegetation of } \\
\text { uncultivated fallow }\end{array}$ & 60 & 60 & 60 & 60,9 & 39,0 & 50,0 & 120,9 & 99,0 & 110,0 \\
\hline $\begin{array}{c}\text { Dobilu isèlis } \\
\text { Undersowing clover }\end{array}$ & 0 & 0 & 0 & 76,5 & 20,3 & 48,4 & 76,5 & 20,3 & 48,4 \\
\hline $\begin{array}{l}\text { Aliejiniai ridikai } \\
\text { Oil radishes }\end{array}$ & 30 & 30 & 30 & 44,1 & 42,5 & 43,3 & 74,1 & 72,5 & 73,3 \\
\hline
\end{tabular}

${ }^{*}$ Rotacijos / Rotations. 
$97,7 \%)$. Dar tampresnis ryšys nustatytas su iterptu biologinio azoto kiekiu $-\mathrm{R}^{2}=0,69$ (koreliacinio santykio tikimybès lygis 99,8\%).

Žieminių rugių derlius ir cheminè sudètis. Žieminių rugių derliui, priklausomai nuo tręšimo varianto, įtakos turèjo žaliosios trąšos biologinis azotas ir mineralinių trąšų azotas. Kaip buvo mi- nèta, (variantas be organinių trąšų) žieminiai rugiai buvo tręšiami mineralinių trąšų vidutinemis normomis $\left(\mathrm{N}_{80} \mathrm{P}_{60} \mathrm{~K}_{60}\right)$, kurios turëjo kompensuoti derliaus sukauptus maisto elementus. Priklausomai nuo vegetacijos periodo sąlygų, patręšus žieminius rugius tik mineralinemmis trąšomis $\mathrm{N}_{80}$, jie subrandino vidutinškai $2,96 \mathrm{t} \mathrm{ha}^{-1}$ grūdų ( 3 pav.). Dobilų ato-
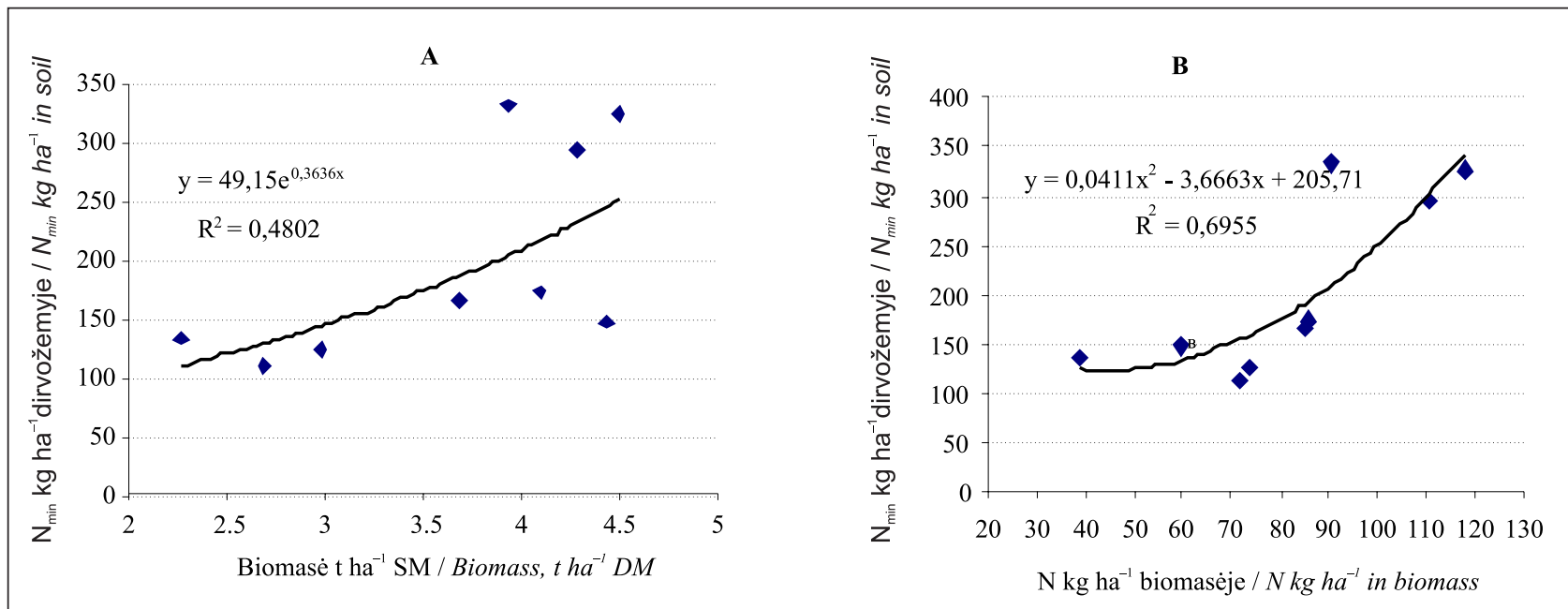

2 pav. Mineralinio azoto atsargų (0-100 cm sluoksnyje) priklausomumas nuo įterpto žaliosios trą̌sos biomasès kiekio (A) ir sukaupto joje azoto (B)

Fig. 2. Dependence of mineral nitrogen stocks $(0-100 \mathrm{~cm}$ layer) on the amount of an inserted green manure biomass (A) and nitrogen accumulated in it (B)



3 pav. Mineralinių azoto trąšų ir žaliosios trąšos ịtaka žieminių rugių grūdų derliui (A) ir jo priklausomumas nuo mineralinio azoto kiekio dirvožemyje (0-100 cm sluoksnyje) pavasarį (B)

Fig. 3. Influence of mineral nitrogen fertilizer and green manure on winter rye grain yield $(A)$ and its dependence on the amount of mineral nitrogen in the soil (0-100 cm layer) in spring (B) 
lo ir lubinų žaliosios trąšos poveikis grūdų derliui netręšiant jų pavasarị mineralinèmis azoto trąšomis buvo iš esmès 15,6-27,6 \% mažesnis. Tai rodo, kad sukauptas žaliosios trąšos biomasèje azotas, nors pagal kiekị buvo analogiškas mineralinių trąšų normai, bet tik iš dalies patenkino žieminių rugių augalų azoto poreikị, nes dalis kiekio prarandama dèl išplovimo rudens-žiemos laikotarpiu. Vakarų Lietuvos priemolio dirvožemiuose dobilų poveikis žieminių rugių derliui gali būti didesnis. R. Skuodienès ir N. Daugèlienès (2008) duomenimis, užartas antrų metų raudonụjų dobilų atolas padidino žieminių rugių derlių $0,35 \mathrm{t} \mathrm{ha}^{-1}$. Tačiau tai gali būti siejama su didesniu kiekiu sukaupto biologinio azoto, auginant dobilus dvejus metus. Nors su nedirbamo pūdymo augalija ir buvo įterpta beveik perpus mažiau biologinio azoto nei su dobilų atolu arba lubinais, tačiau kartu pavasarị ịterptas mineralinių trąšų azotas $\mathrm{N}_{60}$ optimizavo mitybos sąlygas. Palyginti su tręšimu tik mineralinèmis trąšomis $\mathrm{N}_{80}$, grūdų derlius iš esmès padidejo $0,34 \mathrm{t} \mathrm{ha}^{-1}$ arba $11,5 \%$.

Analizuojant atskirų rotacijų mūsų tyrimų duomenis galima pažymèti, kad sausringais metais žaliosios trąšos poveikis žieminių rugių derliui buvo silpnesnis dèl mineralizacijos procesų aktyvumo sumažejimo ir silpnesnès likusių po žiemos nesuskaidytų organinių medžiagų mineralizacijos. Netiesiogiai tai patvirtina 1000 grūdų masès pokyčiai. Esant palankiam derliaus formavimuisi hidroterminiu režimu (II rotacija), augintų po I n. m. dobilų atolo ir lubinų žieminių rugių 1000 grūdų masė palyginti su kontroliniu variantu, buvo 8,0-10,0 \% didesne, o esant sausringoms sąlygoms (I rotacija) - skirtumai buvo neesminiai $(0,9-3,7 \%)$ (2 lentelè). Esant pakankamai drègnam vegetacijos periodui, žaliosios trą̧̌os biologinis azotas turejo ịtakos ir azoto koncentracijai žieminių rugių grūduose. Jeigu pirmojoje rotacijoje labiau azotingi buvo tręštų mineralinėmis azoto trąšomis žieminių rugių grūdai, tai antrojoje rotacijoje - auginti po I n. m. dobilu atolo ir lubinų (+5,5-6,3\%) (2 lentelè). Didesnè azoto koncentracija grūduose liudija apie palankesni azoto režimą žieminių rugių augalų mitybai per visą vegetacijos laikotarpị. Žieminių rugių derliaus ir grūdų kokybinių parametrų atžvilgiu, labiau efektyvus buvo sumažintų mineralinių azoto trąšu $\left(\mathrm{N}_{60}\right)$ ir žaliosios trąšos derinimas. Sausringomis vegetacijos periodo sąlygomis (I rotacija) grūdų derliaus priedas dèl tręšimo žaliaja trąša buvo didesnis $(+19,7 \%)$ nei pakankamo drègnumo sąlygomis antrojoje rotacijoje $(+6,8 \%)$.

Panašius rezultatus skelbia ir A. Nedzinskas (1999). Jo tyrimų duomenimis, geriausiai žieminiai rugiai derejo, patręšus juos mineralinèmis azoto trąšomis $\mathrm{N}_{80}$ užartos lubinų žaliosios trąšos fone. Palyginti su juoduoju pūdymu, grūdų derlius padidejo $11,6-13,9 \%$.

Mūsų tyrimų duomenys rodo, kad grūdų derlius didejo proporcingai mineralinio azoto kiekiui dirvožemyje, t. y. žieminių rugių grūdų derliaus ir

2 lentelè. Mineralinių azoto trąšų ir žaliosios trąšos įtaka žieminių rugių 1000 grūdų masei ir azoto koncentracijai

Table 2. Influence of mineral nitrogen fertilizer and green manure on nitrogen concentration and the weight of 1000 grains of winter rye

\begin{tabular}{|c|c|c|c|c|c|c|}
\hline \multirow{2}{*}{$\begin{array}{l}\text { Organinès medžiagos } \\
\text { šaltinis } \\
\text { Sources of organic matter }\end{array}$} & \multicolumn{3}{|c|}{$\begin{array}{l}1000 \text { grūdų masė g } \\
1000 \text { grain weight, } g\end{array}$} & \multicolumn{3}{|c|}{$\begin{array}{l}\text { Azoto koncentracija grūduose } \mathrm{mg} \mathrm{kg}^{-1} \\
\text { Nitrogen concentration in grain, } \mathrm{mg} \mathrm{kg}^{-1}\end{array}$} \\
\hline & $I^{* *}$ & II & $\begin{array}{l}\text { Vidurkis } \\
\text { Average }\end{array}$ & $I^{*}$ & II & $\begin{array}{l}\text { Vidurkis } \\
\text { Average }\end{array}$ \\
\hline $\begin{array}{c}\text { Be organinių trąšų } \\
\text { Without organic fertilizers }\end{array}$ & 32,4 & 29,30 & 30,8 & 2,03 & 1,27 & 1,65 \\
\hline $\begin{array}{l}\text { I n. m. dobilų atolas } \\
\text { I yr. clover aftermath }\end{array}$ & $33,6^{*}$ & $32,22^{*}$ & $32,91^{*}$ & 1,67 & 1,35 & 1,51 \\
\hline Lubinai / Lupine & $32,7^{\star}$ & $31,65^{*}$ & $32,18^{\star}$ & 1,69 & 1,34 & 1,52 \\
\hline $\begin{array}{l}\text { Nedirbamo pūdymo } \\
\text { augalija / Vegetation of } \\
\text { uncultivated fallow }\end{array}$ & 32,2 & $30,81^{*}$ & $31,5^{\star}$ & 2,01 & 1,33 & 1,67 \\
\hline $\mathrm{R}_{05} / L S D_{05}$ & 0,280 & 1,221 & 0,626 & & & \\
\hline
\end{tabular}

* Patikimas skirtumas esant $95 \%$ tikimybès lygiui / Significant difference at $95 \%$ probability level.

$* *$ Rotacijos / Rotations. 
mineralinio azoto atsargų dirvožemyje ryšys buvo vidutinio stiprumo $\left(\mathrm{R}^{2}=0,47\right.$, koreliacinio santykio tikimybès lygis 94,9\%). Kaip ir dèl tręšimo pupinių augalų žaliąja trąša, nedirbamo pūdymo augalijos aparimas, palyginti su tręšimu tik mineralinèmis trą̧̌omis $\mathrm{N}_{80}$, iš esmès didino 1000 grūdų masę $(+0,7 \mathrm{~g})$. Azoto koncentracija grūduose keitėsi nežymiai.

Miežiu derlius ir cheminè sudètis. Miežiams, kaip žalioji trąša, buvo naudoti posèlinių aliejinių ridikų ir dobilų i̇sèlio pasèliai. Dviejų rotacijų duomenimis, aparus juos spalio antrajji dešimtadieni, $\mathfrak{i}$ dirvožemị buvo ịterptas panašus kiekis azoto - atitinkamai 43,3 ir 48,4 $\mathrm{kg} \mathrm{ha}^{-1} \mathrm{~N}$ (1 lentelè). Posèlinių augalų panaudojimas miežių tręšimui, papildomai netręšiant mineralinèmis trąšomis, nepasiteisino. Abiejose rotacijose grūdų derlius buvo akivaizdžiai $(62,2 \%)$ mažesnis nei tręštų tik mineralinèmis trąšomis $\mathrm{N}_{80}$ (4 pav.) Azoto trąšų normos mažinimas $\left(\mathrm{N}_{30}\right)$ užartos aliejinių ridikų žaliosios trą̌sos fone taip pat buvo mažiau efektyvus ir tik esant palankioms hidroterminèms sąlygoms vegetacijos metu (II rotacija) derliaus skirtumas (palyginti su kontroliniu variantu) buvo neesminis. Analogiškus rezultatus apie neesminę žaliosios trąšos įtaką javų derliui publikuoja Olsen ir kt. (2009). Kitu autorių duomenimis, posèlinè žalioji trąša gali iš es- mès didinti po jų auginamų augalų derlių (Tapio Lahti, Kuikman, 2003; Nemeikšienė ir kt., 2010). A. Baniūnienè (2003), atlikusi tyrimus priesmèlio dirvožemyje, nustatè, kad posèlyje augintų lubinų žaliosios trąšos poveikis miežių derliui buvo svarbus ir antraisiais poveikio metais - grūdų derlius padidèjo $10 \%$.

Skirtingi efektyvumo rezultatai leidžia daryti prielaidą, kad posėlinių augalų poveikis javų derliui labai priklauso nuo rudens laikotarpiu suformuoto biomasès kiekio. Pavyzdžiui, šių tyrimų metu sukaupto dobilu biomaseje azoto kiekis pirmojoje ir antrojoje rotacijoje skyrèsi 4 kartus ir tai turèjo ittakos dirvožemio mineralinio azoto atsargoms bei miežių mitybos sąlygoms. Regresinès analizès duomenimis, miežių grūdų derlius vidutiniškai koreliuoja su mineralinio azoto kiekiu pavasari $\left(\mathrm{R}^{2}=0,58\right.$, koreliacinio santykio tikimybès lygis $83,6 \%$ ), o tai atitinka kitų tyrejuc nustatytus dèsningumus (Mengel et al., 2005; Vaišvila et al., 2005).

Žaliosios trąšos azoto įtaka miežių 1000 grūdų masei ir azoto koncentracijai grūduose buvo silpnai išreikšta, nes įterptas su biomase azoto kiekis buvo nedidelis (3 lentelè).

Be to, dalis mineralinio azoto buvo prarasta dèl išsiplovimo žiemos-pavasario laikotarpiu. Auginant miežius tik užartos žaliosios trąšos (do-

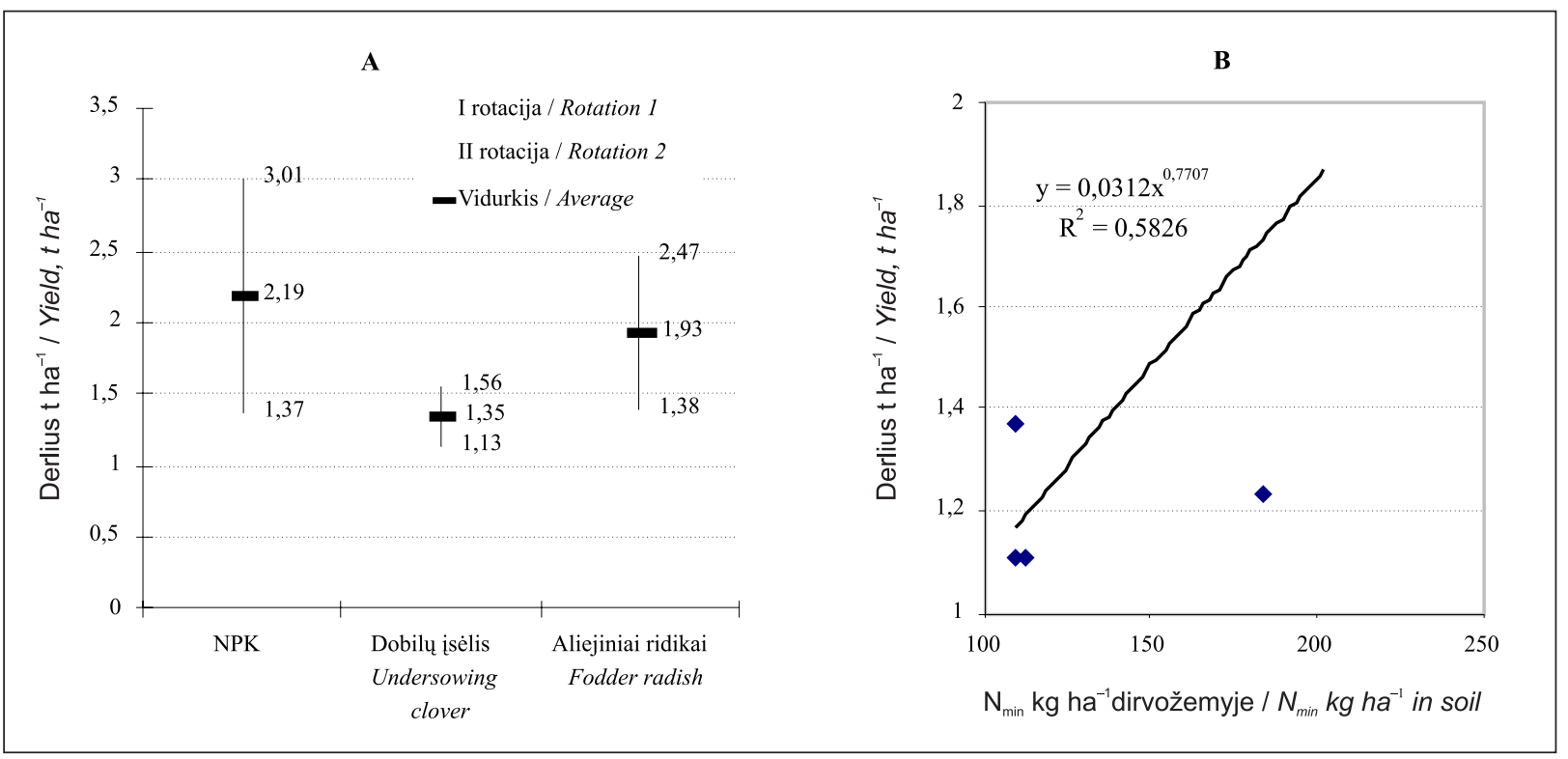

4 pav. Tręšimo ịtaka miežių grūdų derliui (A) ir jo priklausomumas nuo mineralinio azoto kiekio dirvožemyje (0-100 cm sluoksnyje) pavasarị (B)

Fig. 4. Influence of fertilization on barley grain yield $(A)$ and its dependence on the amount of mineral nitrogen in the soil (0-100 cm layer) in spring (B) 
3 lentelè. Mineralinių azoto trąšų ir žaliosios trąšos ịtaka miežių 1000 grūdų masei ir azoto koncentracijai Table 3. Influence of mineral nitrogen fertilizer and green manure on nitrogen concentration and the weight of 1000 grains of barley

\begin{tabular}{|c|c|c|c|c|c|c|}
\hline \multirow{2}{*}{$\begin{array}{l}\text { Organinès medžiagos } \\
\text { šaltinis } \\
\text { Source of organic matter }\end{array}$} & \multicolumn{3}{|c|}{$\begin{array}{l}1000 \text { grūdų masė g } \\
1000 \text { grain weight, } g\end{array}$} & \multicolumn{3}{|c|}{$\begin{array}{l}\text { Azoto koncentracija grūduose } \mathrm{mg} \mathrm{kg}^{-1} \\
\text { Nitrogen concentration in grain, } \mathrm{mg} \mathrm{kg}{ }^{-1}\end{array}$} \\
\hline & $I^{* *}$ & II & $\begin{array}{c}\text { Vidurkis } \\
\text { Average }\end{array}$ & $I^{*}$ & II & $\begin{array}{l}\text { Vidurkis } \\
\text { Average }\end{array}$ \\
\hline $\begin{array}{c}\text { Be organinių trąšu } \\
\text { Without organic fertilizers }\end{array}$ & 40,3 & 38,0 & 39,2 & 2,59 & 2,77 & 2,68 \\
\hline $\begin{array}{c}\text { Dobilų isèlis } \\
\text { Undersowing clover }\end{array}$ & $38,4^{*}$ & $35,4^{*}$ & 36,9 & 2,41 & 2,63 & 2,52 \\
\hline $\begin{array}{l}\text { Aliejiniai ridikai } \\
\text { Fodder radishes }\end{array}$ & 40,5 & 38,3 & 39,4 & 2,53 & 2,60 & 2,57 \\
\hline $\mathrm{R}_{05} / L S D_{05}$ & 0,351 & 1,882 & 0,957 & & & \\
\hline
\end{tabular}

* Patikimas skirtumas esant $95 \%$ tikimybès lygiui / Significant difference at $95 \%$ probability level.

${ }^{* *}$ Rotacijos / Rotations.

bilų ịsèlio) fone, grūdai buvo smulkesni ir mažiau azotingi (palyginti su tręštais mineralinèmis trąšomis $\left.\mathrm{N}_{80}\right)$.

\section{IŠVADOS}

1. Priesmèlio dirvožemyje pagrindiniai sejomainos augalai žaliajai trąšai (I n. m. dobilų atolas, geltonieji lubinai, nedirbamo pūdymo augalija) iki aparimo žiemkenčių tręšimui liepos mènesị suformuoja vidutiniškai $3,10-3,74 \mathrm{t} \mathrm{ha}^{-1}$ sausųjų medžiagų biomasès, su kuria ị dirvožemị ịterpiama 50,0-83,6 kg ha ${ }^{-1}$ azoto. Tarpinių pasèlių žaliajai trąšai (dobilų ịseelio, aliejinių ridikų) produktyvumas mažesnis ir pasižymi didesne variacija nei pagrindinių sèjomainos augalų. Nuo antsèlio nuèmimo iki aparimo spalio ménèsị jie užaugina vidutiniškai $1,29-2,14 \mathrm{t} \mathrm{ha}^{-1}$ sausųjų medžiagų biomasès, su kuria įterpiama 43,3-48,4 $\mathrm{kg} \mathrm{ha}^{-1} \mathrm{~N}$.

2. Priesmèlio dirvožemyje žieminių rugių ir miežių tręšimas tik žaliosios trąšos biomase nepasiteisino - javų grūdų derlius, palyginti su tręšimu mineralinèmis azoto trąšomis $\mathrm{N}_{80}$, sumažèjo iš esmès: žieminių rugių - 15,6-27,6 \%, miežių - 62,2 \%. Efektyvus buvo žaliosios trąšos (nedirbamo pūdymo augalijos) ir sumažintų $25 \%\left(\mathrm{~N}_{60}\right)$ mineralinių azoto trąšų derinimas. Taip tręšiant gautas didžiausias žieminių rugių grūdų derlius $\left(3,30 \mathrm{t} \mathrm{ha}^{-1}\right)$, grūdai buvo iš esmès stambesni $(+0,7 \mathrm{~g})$.

3. Žaliosios trąšos azotas didino žieminių rugių 1000 grūdų masę vidutiniškai 4,5-6,9\%, o azoto koncentracija grūduose reikšmingai nesikeitè.
Posèliniai augalai (aliejiniai ridikai, dobilų ịsèlis), panaudoti miežių tręšimui, azoto koncentracijai miežių grūduose ir jų stambumui įtakos neturèjo.

\section{PADE்KA}

Straipsnyje pateikiami tyrimų rezultatai, gauti vykdant ilgalaikę LAMMC mokslinių tyrimų programą „Žemès ūkio bei miškų dirvožemių našumas ir tvarumas".

Gauta 20111212

Priimta 20120327

\section{LITERATŪRA}

1. Arlauskienè A., Maikštėnienė S. 2005. Skirtingų biologinių savybiu augalų panaudojimas dirvožemyje biogeniniams elementams kaupti ir filtracinių vandenų taršai mažinti. Ekologija. Nr. 2. P. 54-65.

2. Baniūnienè A. 2003. Posèlinių augalų žaliosios trąšos itaka bulvių derliaus produktyvumui. Žemdirbysté: mokslo darbai. T. 81(1). P. 73-84.

3. Brye K. R., Norman J. M., Bundy L. G., Gower S. T. 2001. Nitrogen and carbon leaching in Agroecosystems and their role in denitrification potential. Journal of Environmental Quality. Vol. 30. P. 58-70.

4. Granstedt A. 1995. The mobilization and immobilization of soil nitrogen after green manure crops at three locations in Sweden. Soil Management in Sustainable Agriculture. Wye College, University of London. P. 265-282. 
5. Hamdy Y. A. 1982. Application of nitrogen-fixing systems in soil improvement and management. Soils Bulletin. Rome. Vol. 49. 188 p.

6. Krištaponytė I., Maikštėnienè S. 2006. Ilgalaikio ìvairaus intensyvumo tręšimo poveikis glejjiškų rudžemių našumui. Žemès ūkio mokslai. Nr. 3. P. 1-9.

7. Maikštènienė S., Velykis A., Arlauskienė A. ir kt. 2008. Tausojamoji žemdirbystė našiuose dirvožemiuose: monografija. Akademija, Kèdainių r.: Lietuvos žemdirbystès institutas. 344 p.

8. Mengel K., Hütsch B., Kane Y. 2005. Nitrogen fertilizer application rates on cereal crops according to available mineral and organic soil nitrogen. European Journal of Agronomy. Vol. 24(4). P. 343348.

9. Nedzinskas A., Nedzinskienè T. 1999. Augalai žaliajai trąšai lengvuose dirvožemiuose. Žemdirbystė: mokslo darbai. T. 66. P. 37-43.

10. Nemeikšienė D., Arlauskienė A., Šlepetienė A. et al. 2010. Mineral nitrogen content in the soil and winter wheat productivity as influenced by the pre-crop grass species and their management. Žemdirbyste-Agriculture. Vol. 97(4). P. 23-36.

11. Olesen J. E., Askegaard M., Rasmussen I. A. 2009. Winter cereal yields as affected by animal manure and green manure in organic arable farming. European Journal of Agronomy. Vol. 30(2). P. 119128.

12. Orlov D. S., Sadovnikova L. K. 1996. Nontraditional ameliorants and organic fertilizers. Eurasian Soil Science. Vol. 29. No. 4. P. 474-479.

13. Rudokas V. 2003. Sideracinių augalų agrobiologinis įvertinimas bulvių sejomainoje. Žemdirbysté: mokslo darbai. T. 81. Nr. 1. P. 128-141.

14. Romanovskaja D. 2001. Ivairių organinių trąšų ịtaka organinès medžiagos kaupimuisi ir mineralinio azoto dinamikai velèniniame jauriniame priesmèlio dirvožemyje. Žemés ūkio mokslai. Nr. 1. P. 3443.

15. Skuodienė R., Daugielienė N. 2008. Daugiamecių žolių, panaudotų kaip žalioji trąša, įtaka žieminių kvietrugių ir rugių produktyvumui. ŽemdirbystéAgriculture. T. 95. Nr. 2. P. 72-87.

16. Stancevičius A., Bogužas V., Trečiokas K. 1996. Tarpinių pasèlių vaidmuo Lietuvos žemdirbystèje. Žemdirbystés mokslo dabartis ir ateitis. Mokslinès konferencijos pranešimai. Dotnuva-Akademija. P. 108-115.

17. Stancevičius A., Trečiokas K. 1996. Tarpinių pasèlių ittaka pafermio sejjomainų produktyvumui. Žemdirbysté: mokslo darbai. T. 53. P. 116-136.

18. Tapio L., Kuikman P. J. 2003. The effect of delaying autumn incorporation of green manure crop on $\mathrm{N}$ mineralization and spring wheat (Triticum aestivum L.) performance. Nutrient Cycling in Agroecosystems. Vol. 65. P. 265-280.

19. Tarakanovas P., Raudonius S. 2003. Agronominiu tyrimu duomenu statistine analizé taikant kompiu- terines programas ANOVA, STAT, STAT-PILOT iš paketo SELEKCIJA ir IRRISTAT. Akademija. 60 p.

20. Vaišvila Z., Arbačiauskas J., Staugaitis G. 2005. Nitrogen nutrition diagnostics for agricultural crops in Lithuania: 3nd International Nitrogen Conference, Nanjing, China. P. 254-259.

21. Vinther F. P., Hansen E. M., Eriksen J. 2006. Leaching of soil organic carbon and nitrogen in sandy soils after cultivating grass-clover swards. Biology and Fertility of Soils. Vol. 43. P. 12-19.

22. Трипольская Л., Романовская Д. 2006. Зеленое удобрение как источник азота и органического углерода в агроэкосистемах на супесчаных почвах. Проблемы сельского хозяйства. Международный сборник научных трудов. Калининград: КГТУ. С. 97-104.

Liudmila Tripolskaja, Danuta Romanovskaja, Alvyra Šlepetienė, Ingrida Verbylienė

\section{COMPARISON OF THE EFFICIENCY OF GREEN MANURE AND MINERAL FERTILIZERS FOR WINTER RYE AND BARLEY YIELDS IN A SANDY LOAM SOIL}

Sum mary

Possibilities to reduce the application of industrial mineral nitrogen fertilizers in crop rotations of the sustainable farming system by using the biological nitrogen accumulated by green manure crops were evaluated based on the data of stationary experiments performed during the 1997-2005 period in the Voke branch of LRCAF. Investigations were carried out in cereals (barley, barley, winter rye, oat) rotation on a sandy loam Luvisol (Haplic Luvisols) of low acidity, with medium phosphorus content and high potassium level. It was determined that on the sandy loam the main green manure crops (clover aftermath of the 1st year of use, yellow lupine, uncultivated fallow vegetation) had formed more abundant biomass $-3.10-3.74 \mathrm{tha}^{-1}$ of dry matter on average, with which $50.0-83.6 \mathrm{~kg} \mathrm{ha}^{-1}$ of nitrogen had been added to the soil. The productivity of green manure catch crops (clover under-sowing, oilseed radish) was lower and exhibited higher variation than that of the main crop plants. In autumn, the biomass of the dry matter reached an average of $1.29-2.14 \mathrm{t} \mathrm{ha}^{-1}$, which added $43.3-48.4 \mathrm{~kg} \mathrm{ha}^{-1}$ of nitrogen to the soil. The application of green manure exclusively for winter rye and barley fertilization on the sandy loam soil was not successful - cereal harvest substantially decreased compared to fertilization with mineral nitrogen fertilizers $\mathrm{N}_{80}$ : for winter rye - by $15.6-27.6 \%$, for barley - by $62.2 \%$. A combination of the uncultivated fallow vegetation for green manure and nitrogen fertilizer $\left(\mathrm{N}_{60}\right)$ rates reduced by $25 \%$ was efficient. This variant of fertilization ensured the highest winter rye grain yield (3.30 $\left.\mathrm{t} \mathrm{ha}^{-1}\right)$; grains were also significantly larger $(+0.7 \mathrm{~g})$.

Key words: green manure, cereals, yield, nitrogen 